\title{
PENERAPAN SUPPORT VECTOR MACHINE UNTUK PENDETEKSIAN DAN KLASIFIKASI MOTIF PADA CITRA BATIK BESUREK MOTIF GABUNGAN BERDASARKAN FITUR HISTOGRAM OF ORIENTED GRADIENT
}

\author{
Dita Retnowati ${ }^{1}$, Ernawati ${ }^{2}$, Kurnia Anggriani ${ }^{3}$ \\ ${ }^{1,2,3}$ Program Studi Informatika, Fakultas Teknik, Universitas Bengkulu. \\ Jl. W.R. Supratman Kandang Limun Bengkulu 38371A INDONESIA \\ (telp: 0736-341022; fax: 0736-341022) \\ ${ }^{1}$ dita.retnowati07@gmail.com \\ ${ }^{2}$ w ier nadyahoo.com \\ ${ }^{3}$ kurniaanggriani@unib.ac.id
}

Abstrak: Batik Besurek memiliki karakter dan motif yang khas dan unik. Tujuan dari penelitian ini adalah membangun aplikasi yang dapat mendeteksi dan mengklasifikasi motif batik Besurek menggunakan Histogram of Oriented Gradient untuk ekstraksi fitur dan Support Vector Machine untuk klasifikasi motif batik besurek. Penelitian ini terfokus pada motif berikut; Kaligrafi, Rafflesia, dan Burung Kuau. Aplikasi ini dibangun dengan Matlab 2014. Berdasarkan hasil pengujian aplikasi diperoleh akurasi dari proses deteksi pada citra yang telah dilatih, citra yang belum dilatih, dan citra non Besurek masing-masing yaitu; (a) 83,06\%,(b) 86,87\%, dan (c) 84,69\%. Sedangkan akurasi dari proses klasifikasi pada citra yang telah dilatih, citra yang belum dilatih, dan citra non-besurek masing-masing yaitu; (a) $100 \%$, (b) $89,33 \%$, dan $0 \%$.

Kata Kunci: deteksi dan klasifikasi, batik besurek, histogram of oriented gradient, dan support vector machine

Abstract: Batik Besurek has unique character and motif. The purpose of this research is to build an application that can detect and classify batik Besurek's motif using Histogram of Oriented Gradient for feature extraction and Support Vector Machine for classification of batik Besurek's motif. This research focuses on the following motives; Kaligrafi, Rafflesia, and Burung Kuau. This application is built with Matlab 2014. Based on the results of application testing obtained the accuracy of the detection process on the image that has been trained, the image that has not been trained, and nonBesurek image that is; (a) $83,06 \%$,(b) $86,87 \%$, dan (c) $84,69 \%$. While the accuracy of the classification process on the image that has been trained, the image that has not been trained, and non-Besurek image that is; (a) 100\%, (b) 89,33\%, and $0 \%$.

Keywords: detection and classification, besurek batik, histogram of oriented gradient, and support vector machine 
Jurnal Pseudocode, Volume V Nomor 2, September 2018, ISSN 2355-5920 www.ejournal.unib.ac.id/index.php/pseudocode

\section{PENDAHULUAN}

Batik Besurek memiliki karakter dan motif yang khas dan unik [1]. Batik Besurek memiliki beragam motif diantaranya Rafflesia, Kaligrafi dan Burung Kuau, Relung Paku dan Rembulan. Kelima motif tersebut termasuk ke dalam motif dasar batik Besurek. Dalam setiap kain batik Besurek, terkandung satu atau lebih motif. Citra batik yang mengandung lebih dari satu motif artinya mengandung beberapa motif dasar. Misalnya dalam satu kain batik Besurek terdapat motif Kaligrafi dan Rafflesia.

Pengenalan motif yang terdapat didalam suatu kain batik Besurek dapat dilakukan dengan proses klasifikasi, yaitu mengklasifikasikan motif-motif yang terkandung dalam kain batik Besurek ke dalam kelasnya masing-masing. Penelitian mengenai klasifikasi batik menjadi beberapa kelas pernah dilakukan. Namun, pada umumnya penelitian tersebut hanya mengklasifikasikan citra batik yang memiliki satu motif saja. Pada beberapa kasus, dalam satu citra terdapat beberapa jenis motif dasar batik.

Penelitian terkait klasifikasi batik Besurek pernah dilakukan oleh Yuri Basilka. Dalam penelitian tersebut, klasifikasi citra batik Besurek motif gabungan hanya diklasifikasikan ke dalam satu kelas saja, dengan mengabaikan motif Besurek lainnya yang ada dalam citra tersebut. Tingkat akurasi klasifikasi citra batik Besurek motif gabungan yang didapat adalah sebesar $60 \%$.

Penelitian terkait dengan klasifikasi multi objek pernah dilakukan oleh Dini Amputri dkk. Objek dari penelitian tersebut adalah citra angka kwh meteran dimana terdapat 5 digit angka yang berbeda-beda. Metode yang digunakan dalam penelitian ini adalah Histogram of Oriented Gradient dan Support Vector Machine. Tingkat akurasi klasifikasi angka dalam penelitian ini adalah $86,67 \%$.

Penelitian lain terkait klasifikasi objek dalam sebuah citra pernah dilakukan juga oleh Bhima Caraka menggunakan Support Vector Machine (SVM) dan ekstraksi fitur Histogram of Oriented Gradient (HOG). Pada penelitian ini didapatkan tingkat akurasi sebesar $72,26 \%$ dari deteksi sel darah putih dalam citra mikroskop.

Berdasarkan permasalahan dan penelitian terkait di atas, penulis tertarik untuk merancang sebuah aplikasi untuk mendeteksi dan mengklasifikasi motif pada citra batik Besurek motif gabungan dengan judul 'Penerapan Support Vector Machine untuk Pendeteksian dan Klasifikasi Motif pada Citra Batik Besurek Motif Gabungan Berdasarkan Fitur Histogram of Oriented Gradient'

\section{TINJAUAN PUSTAKA}

\section{A. Batik Besurek}

Batik Besurek merupakan batik tulis tradisional khas Bengkulu dengan motif dominan kaligrafi Arab. Batik khas Bengkulu disebut batik Besurek karena motifnya menyerupai kaligrafi huruf Arab. Selain motif kaligrafi, batik Besurek juga memiliki motif lain yaitu motif Rafflesia dan motif Burung Kuau. Dilihat dari motifnya, batik Besurek dapat dikatakan memiliki karakter dan motif yang khas dan sangat unik [1].

Jenis-jenis motif dasar batik Besurek adalah sebagai berikut [2]:

1. Motif Kaligrafi

2. Motif Rafflesia

3. Motif Burung Kuau

4. Motif Relung Paku

5. Motif Rembulan 
Jurnal Pseudocode, Volume V Nomor 2, September 2018, ISSN 2355-5920

www.ejournal.unib.ac.id/index.php/pseudocode

\section{B. Histogram of Oriented Gradient}

Histograms of Oriented Gradients (HOG) merupakan metode dalam image processing yang digunakan untuk mendeteksi objek. Metode ini menggunakan teknik menghitung nilai gradien dalam daerah tertentu dalam sebuah citra atau gambar. Tiap gambar memiliki karakteristik yang berbeda yang ditunjukkan oleh distribusi gradien. Karakteristik ini diperoleh dengan membagi image ke dalam daerah kecil yang disebut cell. Tiap cell disusun sebuah histogram dari sebuah gradien. Kombinasi dari histogram ini dijadikan sebagai deskriptor yang mewakili sebuah objek [3].

Pemikiran utama di balik deskriptor Histogram of Oriented Gradient (HOG) adalah bahwa penampilan objek dan bentuk lokal dalam sebuah citra dapat digambarkan oleh distribusi intensitas atau arah gradien tepi. Penerapan deskriptor ini dapat dicapai dengan membagi citra ke dalam daerah-daerah kecil yang saling terhubung yang disebut cell, dan untuk setiap cell disusun histogram arah gradien atau orientasi tepi untuk tiap-tiap piksel yang berada di dalam cell. Kombinasi histogram-histogram ini kemudian menyatakan deskriptor. Sedangkan gradien pada masing-masing piksel didapatkan dengan menerapkan filter $\left[\begin{array}{lll}-1 & 0 & 1\end{array}\right]$ dan $\left[\begin{array}{c}-1 \\ 0 \\ 1\end{array}\right]$ [4]. Diagram alir algoritme HOG dapat dilihat pada Gambar 1.

Berikut ini adalah tahapan untuk mencari fitur HOG berdasarkan Gambar 1. Tahap pertama pada ekstraksi fitur HOG adalah menghitung gradien yaitu menghitung perubahan pada intensitas warna melalui operasi central difference. Nilai gradient X dan gradien Y merupakan matriks dengan ukuran citra yang berisi nilai 1 atau 0 . Bernilai 1 jika terdapat perubahan intensitas dan bernilai 0 jika tidak terdapat perubahan.

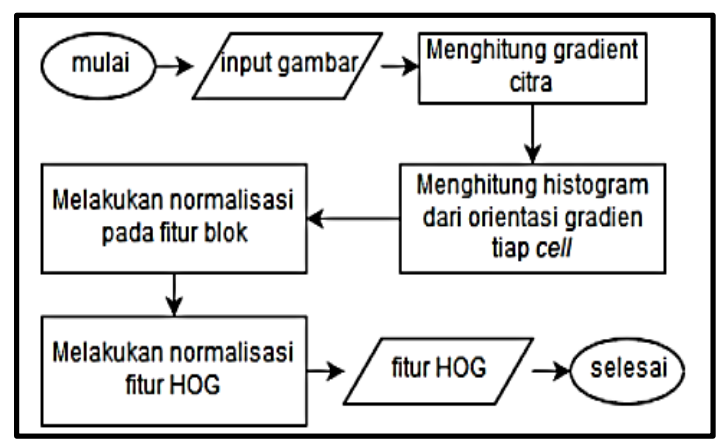

Gambar 1. Algoritme Histogram of Oriented Gradient

Selanjutnya, nilai matriks ini akan digunakan untuk menghitung magnitude (jarak gradient) dan direction (arah gradient) [5]. Magnitude dapat dihitung menggunakan persamaan (1) [6].

$$
|G|=\sqrt{I_{x}^{2}+I_{y}^{2}}
$$

Keterangan:

$\mathrm{G}=$ nilai magnitude gradien citra

$\mathrm{I}_{\mathrm{x}}=$ matriks citra graylevel terhadap sumbu $\mathrm{x}$

$\mathrm{I}_{\mathrm{y}}=$ matriks citra graylevel terhadap sumbu y

$I_{x}$ dan $I_{y}$ dapat dihitung dengan persamaan (2).

$$
I_{x}=I * D_{x}, I_{y}=I * D_{y}
$$

Keterangan:

$\mathrm{D}_{\mathrm{x}}=\operatorname{mask}\left[\begin{array}{lll}-1 & 0 & 1\end{array}\right]$

$\mathrm{D}_{\mathrm{y}}=\operatorname{mask}\left[\begin{array}{c}-1 \\ 0 \\ 1\end{array}\right]$

Sedangkan direction (arah gradient) dapat dihitung dengan persamaan (3).

$$
\theta=\arctan \left(\frac{I_{x}}{I_{y}}\right)
$$

Keterangan:

$\theta=$ direction (arah gradient)

Tahap selanjutnya adalah melakukan perhitungan histogram dari orientasi gradien tiap cell. Setiap piksel dalam sebuah cell mempunyai nilai histogram sendiri-sendiri berdasarkan nilai yang dihasilkan dalam perhitungan gradien yang kemudian dilakukan normalisasi pada setiap blok. Cell memiliki $4 \times 4$ piksel pada sebuah citra. 
Jurnal Pseudocode, Volume V Nomor 2, September 2018, ISSN 2355-5920

www.ejournal.unib.ac.id/index.php/pseudocode

Sedangkan blok memiliki ukuran 2x2 cell. Ilustrasi ditunjukkan pada Gambar 2.

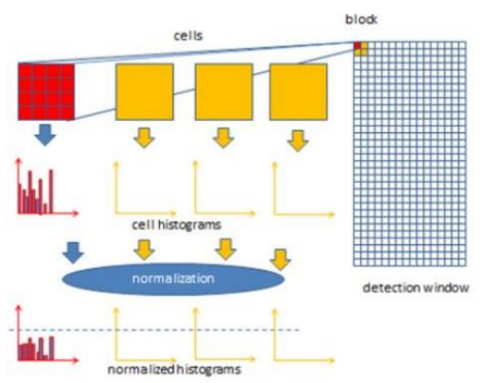

Gambar 2. Cell yang menyusun sebuah blok [6]

Nilai normalisasi fitur blok didapat dari persamaan (4).

$$
b_{i}=\frac{b}{\sqrt{b^{2}+e}}
$$

Keterangan:

$b_{i}=$ blok fitur yang telah dinormalisasi

$\mathrm{E}=$ bilangan positif bernilai kecil untuk mencegah pembagian dengan 0

Nilai normalisasi tiap blok digabungkan menjadi satu vektor menjadi fitur HOG. Kemudian fitur vektor HOG dilakukan normalisasi. Normalisasi dilakukan melalui persamaan (5).

$$
h_{i}=\frac{h}{\sqrt{\|h\|^{2}+e}}
$$

Keterangan:

$b_{i}=$ fitur HOG yang telah dinormalisasi

$\mathrm{e}=$ bilangan positif bernilai kecil untuk mencegah pembagian dengan 0 .

\section{Multi Class Support Vector Machine}

Saat pertama kali diperkenalkan, SVM hanya terbatas untuk mengklasifikasikan data menjadi dua kelas [7]. Namun, dalam perkembangannya penelitian tentang SVM untuk mengklasifikasikan data menjadi beberapa kelas terus dilakukan. Ada dua pilihan untuk mengimplementasikan multi class SVM yaitu dengan menggabungkan beberapa SVM biner atau menggabungkan semua data yang terdiri dari beberapa kelas ke dalam sebuah bentuk permasalahan optimasi. Berikut ini adalah dua metode utama klasifikasi multi class SVM dengan menggunakan pendekatan pertama:

1. Metode "One-against-all"

Dengan menggunakan metode ini dibangun sebanyak $k$ buah model SVM ( $k$ adalah jumlah kelas). Setiap model klasifikasi dilatih dengan menggunakan keseluruhan data untuk mencari solusi permasalahan. Contohnya, terdapat permasalahan klasifikasi dengan 4 buah kelas. Untuk pelatihan digunakan 4 buah SVM biner seperti pada Tabel 1 dan penggunannya dalam mengklasifikasi data baru dapat dilihat pada Gambar 3.

Tabel 1. Contoh 4 SVM biner dengan metode

\begin{tabular}{|c|l|l|}
\hline \multicolumn{3}{|c|}{ One-against-all } \\
\hline $\mathbf{y}_{\mathrm{i}}=\mathbf{1}$ & \multicolumn{1}{|c|}{$\mathbf{y}_{\mathrm{i}=-\mathbf{1}}$} & \multicolumn{1}{c|}{ Hipotesis } \\
\hline Kelas 1 & Bukan Kelas 1 & $f^{1}(x)=\left(w^{1}\right) x+b^{1}$ \\
\hline Kelas 2 & Bukan Kelas 2 & $f^{2}(x)=\left(w^{2}\right) x+b^{2}$ \\
\hline Kelas 3 & Bukan Kelas 3 & $f^{3}(x)=\left(w^{3}\right) x+b^{3}$ \\
\hline Kelas 4 & Bukan Kelas 4 & $f^{4}(x)=\left(w^{4}\right) x+b^{4}$ \\
\hline
\end{tabular}

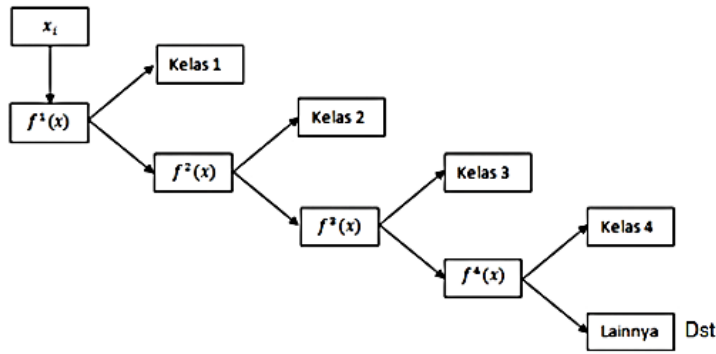

Gambar 3. Contoh klasifikasi dengan metode One-against-all [8]

\section{Metode "One Against One"}

Dengan menggunakan metode ini, dibangun $(k(k-1)) / 2$ buah model klasifikasi biner ( $k$ adalah jumlah kelas). Setiap model klasifikasi dilatih pada data dari dua kelas. Terdapat beberapa metode untuk melakukan pengujian setelah keseluruhan model klasifikasi selesai dibangun. Salah satunya adalah metode voting. Untuk pelatihan digunakan 6 buah SVM biner seperti pada Tabel 2 dan 
Jurnal Pseudocode, Volume V Nomor 2, September 2018, ISSN 2355-5920 www.ejournal.unib.ac.id/index.php/pseudocode

penggunannya dalam mengklasifikasi data baru dapat dilihat pada Gambar 4.

Tabel 2. Contoh 6 SVM biner dengan metode One-against-one

\begin{tabular}{|l|l|l|}
\hline \multicolumn{1}{|c|}{$\mathbf{y}_{\mathbf{i}}=\mathbf{1}$} & $\mathbf{y}_{\mathbf{i}}=\mathbf{- 1}$ & Hipotesis \\
\hline Kelas 1 & Kelas 2 & $f^{12}(x)=\left(w^{12}\right) x+b^{12}$ \\
\hline Kelas 1 & Kelas 3 & $f^{13}(x)=\left(w^{13}\right) x+b^{13}$ \\
\hline Kelas 1 & Kelas 4 & $f^{14}(x)=\left(w^{14}\right) x+b^{14}$ \\
\hline Kelas 2 & Kelas 3 & $f^{23}(x)=\left(w^{23}\right) x+b^{23}$ \\
\hline Kelas 2 & Kelas 4 & $f^{24}(x)=\left(w^{24}\right) x+b^{24}$ \\
\hline Kelas 3 & Kelas 4 & $f^{34}(x)=\left(w^{34}\right) x+b^{34}$ \\
\hline
\end{tabular}

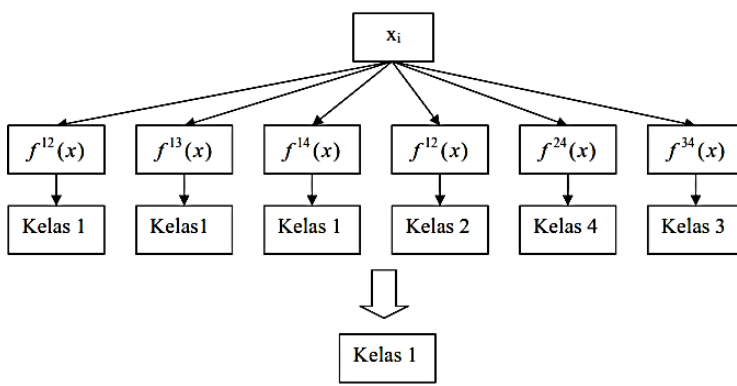

Gambar 4. Contoh klasifikasi metode One-against-one [7]

Jika data $x$ dimasukkan ke dalam fungsi dan hasilnya menyatakan $x$ adalah kelas $i$, maka suara untuk kelas $i$ ditambah satu. Kelas dari data $x$ akan ditentukan dari jumlah suara terbanyak. Jika terdapat dua buah kelas yang jumlah suaranya sama, maka kelas yang indeksnya lebih kecil dinyatakan sebagai kelas dari data. Jadi pada pendekatan ini terdapat $k(k-1) / 2$ buah permasalahan quadratic programming yang masing-masing memiliki $2 n / k$ variabel ( $n$ adalah jumlah data pelatihan).

\section{METODE PENELITIAN}

\section{A. Jenis Penelitian}

Jenis penelitian penerapan Support Vector Machine untuk pendeteksian dan klasifikasi ini termasuk dalam jenis penelitian terapan (applied research).
B. Sarana Pendukung
1. Perangkat Lunak

Perangkat lunak yang mendukung pembuatan aplikasi dalam penelitian ini berupa Sistem Operasi Windows 864 bit, Matlab 2014a, Microsoft Office Visio 2007 dan Balsamic Mock Up.

\section{Perangkat Keras}

Perangkat Keras yang digunakan dalam penelitian ini adalah 1 unit laptop Acer tipe Aspire E 14, printer Canon MP287, dan kamera Nikon Coolpix S2600.

\section{Metode Pengumpulan Data}

Metode pengumpulan data yang digunakan dalam penelitian ini adalah metode dokumentasi. Citra Batik Besurek motif gabungan didapatkan melalui pengrajin batik Besurek atau galeri batik Besurek yang ada di kota Bengkulu.

Citra Batik Besurek didapatkan dengan memfoto Batik Besurek menggunakan kamera Nikon Coolpix S2600. Data citra batik di ambil di beberapa pengrajin batik Besurek atau galeri batik Besurek yang ada di kota Bengkulu diantaranya yaitu:

1) Ben's Collection (Lempuing)

2) Oase Gallery (Jl. Flamboyan)

3) Ovelia Gallery (Tanah Patah)

4) Toko Gading Cempaka (Penurunan)

\section{Metode Pengembangan Sistem}

Metode pengembangan sistem yang digunakan dalam penelitian ini ialah menggunakan model air terjun (waterfall). Model air terjun menyediakan pendekatan alur hidup perangkat lunak secara sekuensial atau terurut dimulai dari analisis, desain, pengodean, pengujian, dan tahap pendukung.

\section{E. Metode Pengujian Sistem}

Proses pengujian sistem yang dilakukan pada penelitian yang dibuat menggunakan metode black box testing. Black box testing adalah metode 
Jurnal Pseudocode, Volume V Nomor 2, September 2018, ISSN 2355-5920

www.ejournal.unib.ac.id/index.php/pseudocode

yang digunakan untuk menguji sistem dengan mengamati hasil eksekusi melalui data uji dan memeriksa fungsional dari perangkat lunak. Teknik pengujian black box yang akan digunakan dalam penelitian ini adalah Equivalance Partitioning, dimana pada teknik ini tiap masukan data akan dikelompokkan ke dalam grup tertentu, yang kemudian akan dibandingkan output-nya. Pada penelitian ini, masukan data dikelompokkan berdasarkan Halaman aplikasi. Halaman aplikasi pada penelitian ini sebanyak 4 yaitu Halaman Utama, Halaman Pelatihan, Halaman Pengujian, dan Halaman Bantuan.

\section{F. Metode Uji Kelayakan Sistem}

Uji kelayakan pada penelitian ini dilakukan dengan cara mengukur persentase akurasi sistem dalam melakukan deteksi dan klasifikasi motif pada citra batik Besurek. Persentase akurasi deteksi dapat diperoleh dengan persamaan (6) [9]. Sedangkan untuk persentase akurasi klasifikasi dapat diperoleh dengan persamaan (7) [10].

$$
\text { Akurasi }=\frac{N_{\text {pred }}}{N_{\text {asli }}}
$$

dimana:

$\mathrm{N}_{\text {pred }}=$ jumlah objek yang berhasil dideteksi

$\mathrm{N}_{\text {asli }}=$ jumlah objek sebenarnya

$$
\text { Akurasi klasifikasi }=\frac{T P+T N}{T P+T N+F P+F N}
$$

dimana:

$$
\begin{aligned}
& T P=\text { True Positive } \\
& T N=\text { True Negative } \\
& F P=\text { False Positive } \\
& F N=\text { False Negative }
\end{aligned}
$$

Persamaan 7 berlaku untuk menghitung akurasi klasifikasi dua kelas yaitu kelas positif dan kelas negatif. Sedangkan dalam penelitian ini terdapat 3 kelas yaitu Rafflesia, Kaligrafi dan Burung Kuau.
Sehingga akurasi klasifikasi dalam penelitian ini dapat diperoleh dengan persamaan 8 .

Akurasi klasifikasi $=\frac{T R+T B k+T K}{T R+T B k+T K+F R+F B k+F K}$

dimana:

$T R=$ True Rafflesia

$T B k=$ True Burung Kuau

$T K=$ True Kaligrafi

$F R=$ False Rafflesia

$F B k=$ False Burung Kuau

$F K=$ False Kaligrafi

\section{ANALISA DAN PERANCANGAN}

\section{A. Analisis Alur Sistem}

Alur sistem adalah tahapan kerja dalam sebuah sistem yang akan dibangun. Sistem ini memiliki 2 tahapan, yaitu tahap pelatihan dan tahap pengujian. Tahap pelatihan adalah tahap melatih citra latih menjadi model svm yang nantinya akan digunakan untuk mengklasifikasi motif batik pada tahap pengujian. Alur tahap pelatihan ditunjukkan oleh Gambar 5.

Gambar 5 menunjukkan diagram alur dari tahap pelatihan. Tahap pelatihan berawal dari mendapatkan ekstraksi ciri dari citra Rafflesia, Burung Kuau dan Kaligrafi yang kemudian disimpan dalam format file mat. Kemudian fitur yang telah didapatkan dilatih dengan menggunakan svmtrain yang menghasilkan model pelatihan motif batik besurek. model pelatihan motif batik besurek disimpan dalam format file mat.

Sedangkan untuk tahap pengujian ditunjukkan pada Gambar 6. Gambar 6 menunjukkan diagram alur dari tahap pengujian. Tahap pengujian berawal dari mendeteksi motif yang ada di dalam citra batik Besurek motif gabungan. Motif-motif yang telah terdeteksi kemudian diekstraksi ciri menggunakan HOG. Setelah diekstraksi, 
Jurnal Pseudocode, Volume V Nomor 2, September 2018, ISSN 2355-5920

www.ejournal.unib.ac.id/index.php/pseudocode

selanjutnya motif diklasifikasikan menggunakan fungsi svmclassify berdasarkan fitur HOG-nya dengan parameter model hasil klasifikasi yang diperoleh pada tahap pelatihan. Kemudian sistem akan menampilkan hasil klasifikasi.

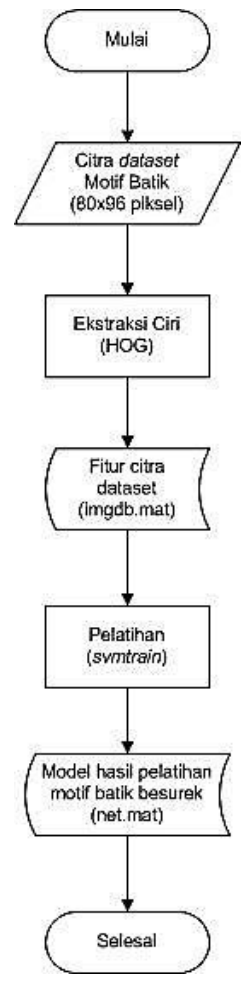

Gambar 5. Flowchart proses pelatihan

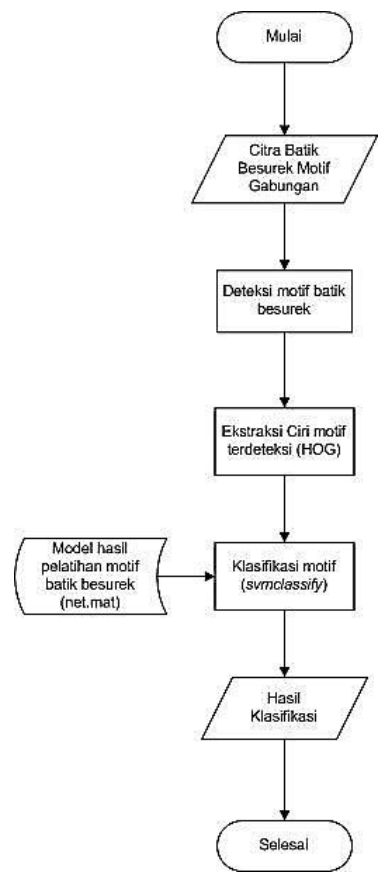

Gambar 6. Flowchart proses pengujian

\section{HASIL DAN PEMBAHASAN}

\section{A. Implementasi Antarmuka}

Pada subbab ini akan dibahas mengenai implementasi antarmuka dari sistem yang telah dibuat. Pada tahapan implementasi antarmuka ini, sistem akan diimplementasikan menggunakan bahasa pemrograman MATLAB R2014a.

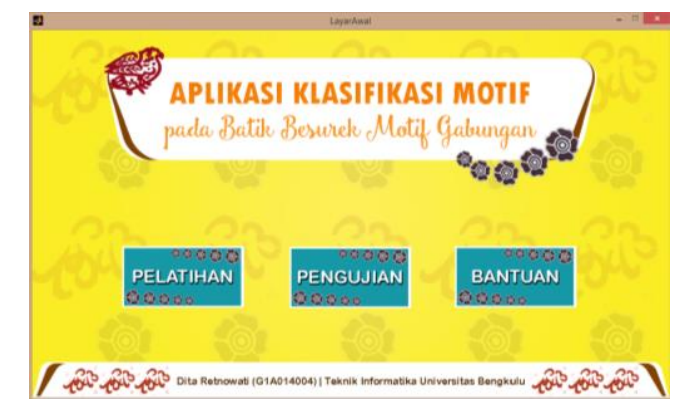

Gambar 7. Halaman Utama Aplikasi

Halaman utama pada sebuah sistem adalah halaman yang memuat topik utama dari sistem. Pada halaman utama ini terdapat 3 menu yaitu menu pelatihan, menu pengujian, dan menu bantuan.

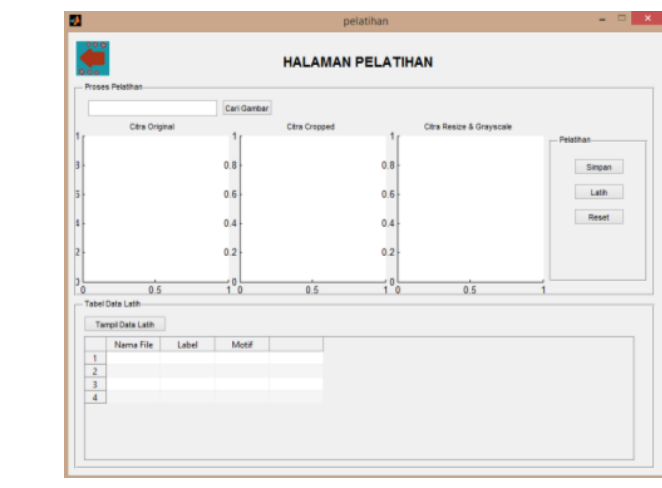

Gambar 8. Halaman Pelatihan

Dapat dilihat pada gambar merupakan tampilan untuk melatih citra batik besurek. Pada halaman ini terdapat 5 button yaitu Cari Gambar, Simpan, Latih, Reset dan Tampil Data Latih. Citra batik Besurek diinputkan dengan menekan button Cari Gambar. Kemudian gambar yang diinputkan di crop bagian motifnya. Setelah di crop, motif dapat disimpan dengan menekan tombol Simpan. Setelah motif disimpan, citra motif batik Besurek dapat 
Jurnal Pseudocode, Volume V Nomor 2, September 2018, ISSN 2355-5920

www.ejournal.unib.ac.id/index.php/pseudocode

dilatih dengan menekan tombol Latih. button Reset berfungsi untuk mengatur tampilan menjadi tampilan default. Sedangkan button Tampil data latih berfungsi untuk menampilkan data latih yang dimiliki oleh sistem.

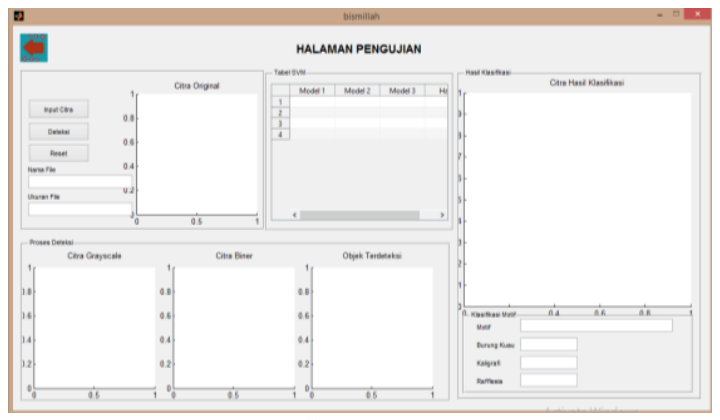

Gambar 9. Halaman Pengujian

Halaman pengujian ditunjukkan oleh Gambar 9 merupakan halaman yang berfungsi untuk melakukan klasifikasi motif pada citra batik Besurek yang diinputkan oleh pengguna. Halaman ini berisi tombol 'Input' untuk memasukkan citra yang akan diklasifikasi motifnya. Tombol 'Reset' berfungsi untuk menghapus semua citra dan data yang ada dihalaman sehingga kembali seperti tampilan default. Pengguna dapat menekan tombol 'Input' untuk mencari citra yang akan diklasifikasi. Citra yang telah dipilih oleh pengguna akan ditampilkan oleh sistem di panel 'Citra Original'. Properti citra berupa nama dan ukuran citra ditampilkan di kolom 'Nama Citra' dan 'Ukuran Citra'.

Tombol 'Deteksi' berfungsi untuk mengklasifikasi citra yang telah diinputkan oleh pengguna. Setelah pengguna menekan tombol 'Deteksi' maka sistem akan menampilkan proses dan hasil klasifikasi. Aplikasi menampilkan proses klasifikasi pada panel 'Citra Grayscale', 'Citra Biner', dan 'Objek Terdeteksi'. Hasil klasifikasi ditampilkan pada panel 'Citra Hasil Klasifikasi' dan panel 'Klasifikasi Motif'.

\section{B. Uji Kelayakan Sistem}

Uji kelayakan sistem akan menampilkan akurasi keberhasilan sebagai tolak ukur dari kelayakan suatu sistem dalam melaksanakan tujuan tertentu. Pada subbab ini akan ditampilkan hasil perhitungan kecepatan kendaraan pada waktu pagi, siang dan sore hari.

1) Pengujian Citra Batik Besurek yang telah Dilatih

Pengujian terhadap citra batik Besurek yang telah dilatih sebanyak 15 citra. Berdasarkan persamaan (1) nilai akurasi klasifikasi yang didapatkan mencapai sebesar 100\%. Hal ini menunjukkan bahwa, citra yang dilatih dapat diklasifikasikan dengan baik oleh sistem. Tabel berikut menunjukkan akurasi klasifikasi setiap citra batik Besurek yang diuji.

2) Pengujian terhadap citra batik besurek yang belum dilatih

Pengujian terhadap citra batik Besurek yang belum dilatih sebanyak 20 citra. Berdasarkan persamaan (1) nilai akurasi klasifikasi yang didapatkan mencapai $89,33 \%$. Hal ini menunjukkan sistem mampu mengklasifikasikan citra yang belum dilatih.

3) Pengujian terhadap citra batik non Besurek

Tujuan dari pengujian citra batik non Besurek adalah untuk mengetahui apakah sistem dapat mengklasifikasikan citra non Besurek. pengujian ini dilakukan pada 5 buah citra batik Besurek. Hasil yang didapatkan yaitu, sistem dapat mengklasifikasikannya, namun kebenaran dari klasifikasi 0\%. Karena kelas batik non Besurek belum diinisialisasikan pada sistem, maka batik non Besurek diklasifikasikan ke dalam kelas yang ada. Tabel berikut menunjukkan akurasi klasifikasi pengujian terhadap citra batik non Besurek: 
Jurnal Pseudocode, Volume V Nomor 2, September 2018, ISSN 2355-5920 www.ejournal.unib.ac.id/index.php/pseudocode

Tabel 3. Akurasi klasifikasi pada pengujian citra batik Besurek terlatih

\begin{tabular}{|c|l|c|c|c|c|c|c|c|}
\hline No & Nama Citra & $\boldsymbol{T B} \boldsymbol{k}$ & $\boldsymbol{T K}$ & $\boldsymbol{T R}$ & $\boldsymbol{F B k}$ & $\boldsymbol{F K}$ & $\boldsymbol{F R}$ & Akurasi \\
\hline 1 & 1-Kaligrafi Rafflesia & 0 & 3 & 1 & 0 & 0 & 0 & $100.00 \%$ \\
\hline 2 & 2-Kaligrafi Rafflesia & 0 & 12 & 7 & 0 & 0 & 0 & $100.00 \%$ \\
\hline 3 & 3-Kaligrafi Rafflesia & 0 & 27 & 1 & 0 & 0 & 0 & $100.00 \%$ \\
\hline 4 & 4-Kaligrafi Rafflesia & 0 & 9 & 2 & 0 & 0 & 0 & $100.00 \%$ \\
\hline 5 & 5-Kaligrafi Rafflesia & 0 & 25 & 4 & 0 & 0 & 0 & $100.00 \%$ \\
\hline 6 & 6-Kaligrafi Rafflesia & 0 & 28 & 6 & 0 & 0 & 0 & $100.00 \%$ \\
\hline 7 & 7-Kaligrafi Rafflesia & 0 & 23 & 9 & 0 & 0 & 0 & $100.00 \%$ \\
\hline 8 & 8-Kaligrafi Rafflesia & 0 & 6 & 6 & 0 & 0 & 0 & $100.00 \%$ \\
\hline 9 & 9-Kaligrafi Rafflesia & 0 & 13 & 2 & 0 & 0 & 0 & $100.00 \%$ \\
\hline 10 & 10-Kaligrafi Rafflesia & 0 & 21 & 3 & 0 & 0 & 0 & $100.00 \%$ \\
\hline 11 & 11-Kaligrafi Rafflesia & 0 & 12 & 1 & 0 & 0 & 0 & $100.00 \%$ \\
\hline 12 & 12-Kaligrafi Rafflesia & 0 & 16 & 2 & 0 & 0 & 0 & $100.00 \%$ \\
\hline 13 & 13-Kaligrafi Burung Kuau & 1 & 18 & 0 & 0 & 0 & 0 & $100.00 \%$ \\
\hline 14 & 14-Kaligrafi Rafflesia & 0 & 12 & 4 & 0 & 0 & 0 & $100.00 \%$ \\
\hline 15 & 15-Kaligrafi Rafflesia & 0 & 3 & 2 & 0 & 0 & 0 & $100.00 \%$ \\
\hline
\end{tabular}

Tabel 4. Akurasi klasifikasi pada pengujian citra batik Besurek belum dilatih

\begin{tabular}{|c|l|c|c|c|c|c|c|c|}
\hline No & \multicolumn{1}{|c|}{ Nama Citra } & $\boldsymbol{T B k}$ & $\boldsymbol{T K}$ & $\boldsymbol{T R}$ & $\boldsymbol{F B k}$ & $\boldsymbol{F K}$ & $\boldsymbol{F R}$ & Akurasi \\
\hline 1 & BU1-Kaligrafi & 0 & 20 & 0 & 0 & 0 & 2 & $90.91 \%$ \\
\hline 2 & BU2-Kaligrafi & 0 & 18 & 0 & 0 & 0 & 0 & $100.00 \%$ \\
\hline 3 & BU3-Kaligrafi Rafflesia & 0 & 13 & 0 & 0 & 4 & 0 & $76.47 \%$ \\
\hline 4 & BU4-Kaligrafi Rafflesia & 0 & 16 & 0 & 0 & 5 & 3 & $66.67 \%$ \\
\hline 5 & BU5-Kaligrafi Rafflesia & 0 & 15 & 1 & 0 & 1 & 1 & $88.89 \%$ \\
\hline 6 & BU6-Kaligrafi & 0 & 3 & 0 & 0 & 0 & 1 & $75.00 \%$ \\
\hline 7 & BU7-Kaligrafi & 0 & 13 & 0 & 0 & 0 & 1 & $92.86 \%$ \\
\hline 8 & BU8-Kaligrafi & 0 & 14 & 0 & 0 & 0 & 0 & $100.00 \%$ \\
\hline 9 & BU9-Kaligrafi Rafflesia & 0 & 6 & 3 & 0 & 0 & 0 & $100.00 \%$ \\
\hline 10 & BU10-Kaligrafi Rafflesia & 0 & 4 & 2 & 0 & 0 & 0 & $100.00 \%$ \\
\hline 11 & BU11-Kaligrafi Rafflesia & 0 & 8 & 4 & 0 & 2 & 0 & $85.71 \%$ \\
\hline 12 & BU12-Kaligrafi Rafflesia & 0 & 8 & 0 & 0 & 3 & 1 & $66.67 \%$ \\
\hline 13 & BU13-Kaligrafi Rafflesia & 0 & 7 & 1 & 0 & 0 & 1 & $88.89 \%$ \\
\hline 14 & BU14-Kaligrafi Rafflesia & 0 & 6 & 1 & 0 & 0 & 1 & $87.50 \%$ \\
\hline 15 & BU15-Kaligrafi Rafflesia & 0 & 11 & 1 & 0 & 0 & 0 & $100.00 \%$ \\
\hline 16 & BU16-Kaligrafi Rafflesia & 0 & 10 & 1 & 0 & 0 & 0 & $100.00 \%$ \\
\hline 17 & BU17-Kaligrafi Rafflesia & 0 & 11 & 0 & 0 & 0 & 1 & $84.62 \%$ \\
\hline 18 & BU18-Kaligrafi Rafflesia & 0 & 1 & 1 & 0 & 0 & 0 & $100.00 \%$ \\
\hline 19 & BU19-Kaligrafi Rafflesia & 0 & 7 & 2 & 0 & 0 & 0 & $100.00 \%$ \\
\hline 20 & BU20-Kaligrafi Rafflesia & 0 & 12 & 2 & 0 & 2 & 1 & $82.35 \%$ \\
\hline & & & & & & $89,33 \%$ \\
\hline
\end{tabular}

Tabel 5. Akurasi klasifikasi pada pengujian citra batik non Besurek

\begin{tabular}{|c|l|c|c|c|c|c|c|c|}
\hline No & \multicolumn{1}{|c|}{ Nama Citra } & $\boldsymbol{T B} \boldsymbol{T}$ & $\boldsymbol{T K}$ & $\boldsymbol{T R}$ & $\boldsymbol{F B} \boldsymbol{F}$ & $\boldsymbol{F R}$ & Akurasi \\
\hline 1 & 1-Batik Betawi & 0 & 0 & 0 & 0 & 7 & 2 & $0.00 \%$ \\
\hline 2 & 2-Batik Tanduk Ruso(Bungo) & 0 & 0 & 0 & 0 & 9 & 3 & $0.00 \%$ \\
\hline 3 & 3-Batik Angso Duo(Jambi) & 0 & 0 & 0 & 0 & 4 & 5 & $0.00 \%$ \\
\hline 4 & 4-Batik Banten & 0 & 0 & 0 & 0 & 14 & 2 & $0.00 \%$ \\
\hline 5 & 5-Batik Mega Mendung Rata-Rata & 0 & 0 & 0 & 0 & 30 & 0 & $0.00 \%$ \\
\hline \multicolumn{7}{|c|}{} \\
\hline
\end{tabular}

\section{KESIMPULAN}

Berdasarkan hasil dan pembahasan yang telah dijabarkan sebelumnya, maka kesimpulan yang dapat diambil adalah sebagai berikut:

1. Penelitian ini telah berhasil menerapkan metode Support Vector Machine untuk mengklasifikasikan motif pada citra batik Besurek motif gabungan berdasarkan fitur Histogram of Oriented Gradient.
2. Pengujian fungsional sistem dengan menggunakan metode black box berhasil $100 \%$.

3. Pada penelitian ini nilai akurasi dari proses deteksi motif citra batik Besurek adalah sebagai berikut:

a. $83,06 \%$ untuk citra yang telah dilatih

b. $86,87 \%$ untuk citra yang belum dilatih

c. $84,69 \%$ untuk citra non batik Besurek 
4. Nilai akurasi klasifikasi motif batik Besurek adalah sebagai berikut:
a. $100 \%$ untuk citra yang telah dilatih
b. $89,33 \%$ untuk citra yang belum dilatih
c. $0 \%$ untuk citra batik non Besurek

5. Warna objek dan gangguan berupa objek yang menutupi dapat mempengaruhi proses deteksi

6. Metode SVM bergantung pada data latih, semakin baik data latih yang dimiliki, semakin baik pula proses klasifikasi.

\section{SARAN}

Berdasarkan hasil dan pembahasan sebelumnnya, maka penulis memberi saran untuk deteksi dan klasifikasi motif pada citra batik Besurek yaitu:

1. Untuk mendapatkan kualitas deteksi yang optimal, perlu mempertimbangkan proses pengambilan citra dengan kondisi yang baik.

2. Sebaiknya aplikasi memiliki lebih banyak jenis citra latih untuk mendapatkan hasil klasifikasi yang lebih baik.

3. Untuk pengembangan selanjutnya, sebaiknya metode ekstraksi fitur dapat untuk proses deskripsi citra dapat menggunakan metode yang lebih baik agar proses klasifikasi lebih baik dan lebih tahan dengan berbagai kondisi pengujian.

\section{DAFTAR PUSTAKA}

[1] Ernawati, "Batik Design Training Sebagai Upaya Pembekalan Soft Skill di Bidang Desain Grafis Terhadap Siswa-Siswi SMK Negeri 5 Kota Bengkulu," Rekursif: Jurnal Informatika, vol. Vol. 3 No. 1 Maret 2015, pp. 54$60,2015$.

[2] Sibarani, "Implementasi AlgoritmeK-Nearest Neighbor untuk Mengklasifikasikan Motif Batik Besurek Bengkulu," Universitas Sumatera Utara, Sumatera Utara, 2015.

[3] H. Liao, "Human Detection Based on Histograms of Oriented Gradients and SVM," 2013. [Online]. Available: https://www.cs.rochester.edu/u/hliao6/projects/human_dete ction/final_project.pdf. [Accessed 20 Januari 2018].

[4] N. Dalal and B. Triggs, "Histograms of Oriented Gradients for Human Detection," 2005. [Online]. Available: https://hal.inria.fr/file/index/docid/548512/filename/hog_cv pr2005.pdf. [Accessed 20 Januari 2018].

[5] D. Amputri, S. Nadra, G. and M. E. Al Rivan, "Perbandingan Jarak Potret dan Resolusi Kamera pada Tingkat Akurasi Pengenalan Angka KwH Meter Menggunakan SVM," Jurnal Ilmiah Informatika Global, Vols. Vol. 8, No. 1, pp. 7-12, 2017.

[6] A. F. Randa , N. Suciati and D. A. Navastara, "Implementasi Metode Kombinasi Histogram Of Oriented Gradients Dan Hierarchical Centroid Untuk Sketch Based Image Retrieval," URNAL TEKNIK ITS, Vols. Vol. 5, No. 2, pp. 311-316, 2016.

[7] K. Sembiring, "Tutorial SVM Bahasa Indonesia," S1 Teknik Informatika, Sekolah Teknik Elektro dan Informatika, ITB , Bandung, 2007.

[8] M. Athoillah, "Pengenalan Wajah Menggunakan SVM Multi Kernel dengan Pembelajaran yang Bertambah," JOIN (Jurnal Online Informatika), vol. Volume 2 No. 2, pp. 84-91, 2017.

[9] J. Sahertian and A. Sanjaya, "Deteksi Buah Pada Pohon Menggunakan Metode Svm Dan Fitur Tekstur," Seminar Nasional Teknologi Informasi dan Multimedia 2017, pp. 19-24, 2017.

[10] B. Caraka, B. A. A. Sumbodo and I. Candradewi, "Klasifikasi Sel Darah Putih Menggunakan Metode Support Vector Machine (SVM) Berbasis Pengolahan Citra Digital," IJEIS, Vols. Vol.7, No.1, pp. 25-36, 2017. 